bacterial infection of a chronic nature. Aflatoxicosis is known to cause immunosuppression by inhibiting protein and nucleic acid synthesis, which could have predisposed the affected birds to bacterial infection ${ }^{2}$.

The 4 principal mycotoxins of concern in birds are aflatoxin $B_{1}$, ochratoxin $A$, deoxynivalenol (vomitoxin) and the trichothecenes. The moulds producing these toxins can grow on various feeds, including grains, peanuts, breads, meat and cheese ${ }^{2}$. The birds in this outbreak were fed seeds but the owner would not allow the feed to be examined for mould and it could not be determined whether all the birds received the same ration. As only the breeding birds were affected it is possible that this group was offered supplements not supplied to the other groups. Breeding birds would also have higher nutritional needs and could hence consume higher, possibly toxic levels of toxins present in or on the feed than birds in other groups.

The isolation of $A$. flavus from the liver and gut of the affected birds lends support to a diagnosis of aflatoxicosis. In cases/outbreaks where it is not possible or economically feasible to analyse the feed for aflatoxin mycotoxins, consideration can be given to using standard methods to isolate fungi from the liver and gut. If A. flavus is found this can lend support to the histopathological findings in making a diagnosis of aflatoxicosis.

\section{REFERENCES}

1. Kelly R F 1992. The liver and biliary system. In Jubb K V F, Kennedy P C, Palmer N (eds) Pathology of domestic animals Vol. 2 (4th edn). Academic Press, San Diego: 319-406

2. Dumonceaux G, Harrison G J 1994. Toxins. In Ritchie B W, Harrison G J, Harrison L R (eds) Avian medicine. Wingers Publishing, Lake Worth: 1034-1049

\author{
Stella S Bastianello ${ }^{\mathrm{a}}$, C C Dolman ${ }^{\mathrm{c}}$, Marijke M Henton ${ }^{\mathrm{b}}$ and Mary-Louise Penrith ${ }^{\mathrm{a}}$

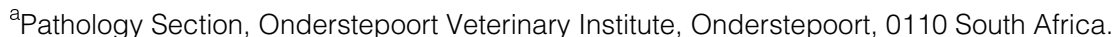 \\ ${ }^{b}$ Bacteriology Section, Onderstepoort Veterinary Institute, Onderstepoort, 0110 South Africa \\ ${ }^{\mathrm{C}}$ Corlett Small Animal Clinic, PO Box 3098, Kenmare, 1745 South Africa.
}

\title{
The possible role of manganese poisoning in enzootic geophagia and hepatitis of calves and lambs
}

Geophagia, or the deliberate ingestion of soil, has been classified as a form of pica, which is usually defined as the compulsive ingestion of inappropriate or foreign material $^{1,5,8,9}$. A specific enzootic form of geophagia occurs in young cattle and sheep on manganese-rich soil derived from the weathering of superficial dolomitic (carbonate) rock formations in the Northern Cape and North-West Provinces. It results in severe subacute to chronic cholangiohepatitis, icterus and a high mortality rate in untreated cases.

Organ specimens from calves characterised by marked icterus, large amounts of ingested black to dark-brown soil, and a severe chronic cholangiohepatitis, have been referred to the Onderstepoort Veterinary Institute (OVI) by veterinarians and farmers sporadically since 1972 . A single lamb submitted had similar lesions. These cases were at first difficult to interpret and were suspected to be due to a plant toxicosis or a chronic infection of the liver. The condition was given the vernacular name of 'Vryburg hepatosis', derived from the district in the North-West Province whence most of the cases originated and the characteristic histopathological changes observed in the liver.

The problem apparently only occurs on 14 farms in the Vryburg, Postmasburg and Barkly West districts of the Northern Cape and North-West Provinces of South Africa. These farms all have outcrops of dolomitic rock reported to be rich in manganese ${ }^{2,3}$. An association between the disease and manganese was therefore suspected.

The soil on the affected farms contains numerous small, round to ovoid, blackgrey manganese-rich iron-containing concretions ca. 1-10 $\mathrm{mm}$ in diameter. Young calves display an insatiable appetite for the manganese-rich soil, sometimes also licking iron poles. The highest frequency of geophagia occurs at 7-14 days, calves older than about 2 months of age rarely being affected. No specific sex or breed predilection could be determined. The symptoms reported usually started with intermittent, progressively worsening geophagia, followed by constipation, dehydration and death within about 7-10 days in untreated cases. Macroscopical pathological changes in affected calves consisted of moderate to severe icterus, a markedly enlarged and yellow liver, and variable amounts of dark-brown to black soil, largely composed of small black to dark-brown manganese-rich concretions, in the stomach and intestines. Histopathology revealed marked cholangiohepatitis of some duration. Morbidity and mortality rates were difficult to estimate accurately, since farmers applied certain preventative measures described below, but owners on severely affected farms estimated that about $50-75 \%$ of calves may develop geophagia, with a mortality rate of close to $100 \%$ in untreated cases.

Liver specimens from 23 calves and 1 lamb with soil in their digestive tracts or a history of geophagia were examined by
Atomic Absorption Spectrometer and revealed high concentrations of manganese, ranging from 10-1800 ppm wet mass (WM) (normal range 2-3 ppm $\mathrm{WM})^{4,6}$. Since liver specimens from 4 fullterm bovine foetuses that had died during dystocia, 4 neonatal calves that had not yet ingested milk, 11 yearling tollies and 15 culled cows from 2 severely affected farms had manganese and iron content within normal limits, it appeared that high levels of manganese must be taken in and accumulated during the pre-weaning period after the ingestion of manganese-rich soil or milk. It was necessary to establish not only the source of the manganese, but whether the observed effects were directly due to manganese intoxication or were the result of mineral interactions, for example suppression of absorption of elements such as iron and cobalt, by manganese.

Milk specimens from cows with calves 1-12 weeks of age from 3 severely affected farms had higher levels of manganese and lower levels of iron than cows under similar grazing conditions at the Onderstepoort and Irene experimental farms chosen as control levels for reference. Grazing plants (red grass, Themeda triandra, and rosyntjiebos, Grewia flava) from affected farms collected during summer 1992 and autumn 1995 revealed higher levels of manganese, and a higher ratio of manganese to iron, than plants from unaffected farms near Vryburg, Irene and Onderstepoort (H J C Smith, 
A J van der Merwe, A H Loock, Institute for Soil, Climate and Water Research, pers. obs., 1993). Soil specimens collected from the surface horizon of grazing areas on 3 affected farms contained more manganese $(7.8 \%$ vs. $0.39 \%)$ and less iron ( $2.4 \%$ vs. $7.8 \%)$, than control specimens collected at the control sites. Faecal samples from cows also had a higher manganese content compared to control levels.

The initial stimulus for the intake of soil by calves and lambs, which is frequently observed, is unknown. Geophagia may be beneficial when it is selective for certain sites and soil types, often termed natural licks, in order to exploit particular nutrient elements, and can be symptomatic for deficiencies of several elements, notably $\mathrm{Na}, \mathrm{Mg}, \mathrm{P}, \mathrm{S}, \mathrm{Cu}, \mathrm{Co}$ and $\mathrm{Mn}^{9}$. Soil-licking may therefore be an instinctive mechanism to secure necessary mineral nutrients in the soil, especially iron, as calves on unsupplemented whole-milk diets have been shown to develop iron deficiency in the absence of soil ${ }^{4}$. It has alternatively been postulated that geophagia may not be a direct response to mineral deficiencies, but may be an instinctive adaptive behavioural response to gastrointestinal disturbances such as nausea, vomiting and diarrhoea ${ }^{8,12}$, or represent displaced appetitive behaviour due to hunger while the cows graze far away for long periods of the day.

On the affected farms, calves temporarily deserted while their dams pursue lush green growth have been observed to start licking small amounts of soil around them, which may often include manganese-rich concretions. Phosphate and sodium deficiency were disregarded as possible causes of geophagia in these calves, since cows and calves on all affected farms had free access to licks that contained both these ingredients in sufficient quantities. Geophagia was reproduced experimentally at both the State Veterinary Laboratory at Vryburg and at OVI by offering manganese-rich soil from affected farms, as well as ordinary red Hutton-type soil from unaffected farms from both Vryburg and Pretoria, to new-born calves and lambs kept in enclosures on concrete floors and fed on colostrum and unsupplemented whole milk. Geophagia of ordinary soil soon ceased, but ingestion of the black manganese-rich soil increased progressively until calves became seriously ill with typical symptoms and had to be euthanased. Dosing with manganese sulphate aggravated this serious form of geophagia in a calf and in 2 lambs. Soil from the stomach contents of affected calves and lambs contained high proportions of manganese to iron.

It is clear from our experiments at OVI that manganese-rich soil, or even manganese sulphate, aggravates ingestion of soil, to produce fatal geophagia in a high percentage of pre-ruminant calves.

It is noteworthy that, while deficiency of manganese has been cited as a cause of geophagia in domestic ruminants ${ }^{9}$, a form of geophagia is described here that apparently results from the excessive ingestion of manganese. Although enzootic geophagia was reproduced in calves and lambs not conceived and born in the enzootic areas, the possible influence of maternal milk in initiating or aggravating this condition cannot be discounted, in view of the elevated levels of manganese in milk from cows from affected farms. Manganese is mainly excreted via the digestive tract, but secretion in milk, especially in colostrum of cows, also occurs, and the amounts secreted can be raised proportionately by increasing the amount of manganese in the $\operatorname{diet}^{6}$.

The manner in which a high intake of manganese produces disease appears to be complex. The main feature of the disease in calves and lambs is liver damage, although the ingestion of soil also leads to variable degrees of constipation and colic that probably cause the calf to stop suckling and contribute to death within a week or two after the commencement of geophagia.

Manganese interferes with iron and cobalt absorption in the digestive tract by competitive binding ${ }^{6,13}$, and has been shown to interfere with the availability of zinc in the digestive tract, as well as with the uptake of cobalt by microorganisms in the rumen ${ }^{11}$. Deficiencies of cobalt have been associated with pica in calves ${ }^{9,14}$ and zinc deficiency has been implicated as a cause of geophagia in children ${ }^{7}$.

According to farmers, the treatment of calves by parenteral injection of commercial iron-dextran compounds and vitamin $B_{12}$ at 1-2 days after birth and at 14 days of age at the registered therapeutic doses per body mass, appeared to have a significant preventative effect on the occurrence of geophagia. Farmers on affected farms also prevent geophagia by rearing calves in enclosures covered with a thick layer of dung to prevent geophagia .

The characteristic histopathological changes in the liver were induced experimentally in 1 calf and in 2 lambs by dosing relatively large amounts of $\mathrm{MnSO} 4$ (Manganous (II) sulphate monohydrate, Univar, Saarchem) over a period of ca. 14 days, after which the calf and lambs developed clinical signs of marked weakness and jaundice and had to be euthanased. The livers of all 3 animals were characterised histologically by marked acute to chronic inflammation of the bile ducts and portal areas. These lesions were indistinguishable from the natural cases of enzootic geophagia, and also corresponded with the changes induced by the experimental dosing and injection of manganous chloride and manganese sulphate in laboratory rodents ${ }^{10,15}$.

It is therefore evident that, although the cause of the geophagia is uncertain, the characteristic lesions in the liver can be attributed to a subacute to chronic form of manganese poisoning. The results of this investigation will be reported in greater detail elsewhere, with particular reference to pathogenesis and pathology.

\section{REFERENCES}

1. Ammerman C B, Loggins P E, Wing J M 1965 Pica - a craving for unnatural food or feeds. Foodstuffs 37: 26-27

2. Astrup J, Tsikos H (in press) Manganese. In Wilson M G C, Annhauser C R (eds) Mineral resources of South Africa. Handbook of Geological Survey of South Africa (6th edn). Council for Geoscience and Geological Survey, Pretoria

3. Beukes N J 1987 Stratigrafie en litofasies van die Cambellrand-subgroep van die proterofitiese Ghaap Groep, Noord-Kaapland. Transactions of the Geological Society of South Africa 83: 141-170

4. Graham T W, Thurmond M C, Mohr F C, Holmberg C A, Anderson M L, Keen C L 1994 Relationships between maternal and foetal liver copper, iron, manganese and zinc concentrations and foetal development in California Holstein dairy cows. Journal of Veterinary Diagnostic Investigation 6: 77-87

5. Halsted J A 1968 Geophagia in man: its nature and nutritional effects. American Journal of Clinical Nutrition 21: 1384-1393

6. Hurley L S, Keen C L 1986 Manganese. In Mertz W (ed.) Trace elements in human and animal nutrition Vol. 1 (5th edn). Academic Press, San Diego: 185-223

7. Hurley L S, Keen C L 1986 Zinc. In Mertz W (ed.) Trace elements in human and animal nutrition Vol. 2 (5th edn). Academic Press, San Diego: 50-51

8. Johns T, Duquette M 1991 Detoxification and mineral supplementation as functions of geophagy. American Journal of Clinical Nutrition 53: 448-456

9. Kreulen D A, Jager T 1984 The significance of soil ingestion in the utilization of arid rangelands by large herbivores, with special reference to natural licks on the Kalahari pans. In Gilchrist F M C, Mackie R I (eds). Herbivore nutrition in the subtropics and tropics. The Science Press, Craighall: 204 221

10. Marshall Findlay G 1924 The production of biliary cirrhosis by salts of manganese. British Journal of Experimental Pathology 5: 92-106

11. Pfander W H, Beck H, Preston R L 1966 The interaction of manganese, zinc and cobalt in ruminants. Federation Proceedings 25: 1362

12. Reid R M 1992 Cultural and medical 
perspectives on geophagy. Medical Anthropology 13: 337-351

13. Thomson A B R, Valberg L S 1972 Intestinal uptake of iron, cobalt and manganese in the iron deficient rat. American Journal of Physiology 223: 1327-1329
14. Valli V E O, Parry B W 1994 The hematopoietic system. In Jubb K V F, Kennedy, P C, Palmer N (eds) Pathology of domestic animals Vol. 3 (4th edn). Academic Press, San Diego: 101-265

15. Witzleben C L, Pitlick P, Bergmeyer J,
Benoit R 1968 Acute manganese overload A new experimental model of intrahepatic cholestasis. American Journal of Pathology 53: 409-403

\author{
J A Neser ${ }^{\mathrm{a}}$, M A de Vries ${ }^{\mathrm{b}}$, Mandy de Vries ${ }^{\mathrm{b}}$, A J van der Merwe ${ }^{\mathrm{c}}, \mathrm{A} \mathrm{H}$ Loock $^{\mathrm{c}}, \mathrm{H} \mathrm{J}$ C Smith ${ }^{\mathrm{c}}$, \\ $\mathrm{F} \mathrm{H}$ van der Vyver ${ }^{\mathrm{d}}$, J H Elsenbroek ${ }^{\mathrm{e}}$ and Rhena Delport \\ ${ }^{a}$ Pathology Section, Onderstepoort Veterinary Institute, Private Bag X05, Onderstepoort, 0110 South Africa. \\ ${ }^{\mathrm{b}}$ State Veterinary Laboratory, Private Bag X36, Vryburg, 8600 South Africa. \\ ${ }^{\mathrm{c}}$ Institute for Soil, Climate and Water, Private Bag X79, Pretoria, 0001 South Africa. \\ dDirectorate of Animal Health, Private Bag X369, Pretoria, 0001 South Africa. \\ ${ }^{e}$ Council for Geoscience and Geological Survey, Private Bag X112, Pretoria, 0001 South Africa. \\ fDepartment of Chemical Pathology, Faculty of Medicine, University of Pretoria, PO Box 2034, \\ Pretoria, 0001 South Africa.
}

$\mathbf{W}^{2}$ etenskaplik is die artikel 'A primary health care approach to an outbreak of cutaneous larva migrans' deur C M E McCrindle, I T Hay, R D Kirkpatrick, J S J Odendaal en E M Calitz (Journal of the South African Veterinary Association, 1996, 67: 133-136) na my mening swak versorg.

1. Ancylostoma word deurgaans as Ancylostomum aangedui. So ook Toxocara leonina in stede van Toxascaris leonina en Dipilidium, in stede van Dipylidium.

2. Volgens die inleiding is voorheen tussen 10 en 15 kinders maandeliks vir velletsels behandel, maar volgens die bespreking het die voorkoms van 15 gevalle per maand na nul gedaal.

3. Tiabendasool se verkoopsnaam word nie genoem nie.

4. Daar is geen aanduiding van die wurmmiddel wat in Junie gebruik is om die gemeenskap se honde te ontwurm, of hoe geslaagd die doseringskampanje ten opsigte van die geskatte proporsie van die gemeenskap se honde was, wat uiteindelik ontwurm is nie. Daar word slegs gestel dat die betrokke firma tydens die Oktober inligtingsdag gratis monsters 'Telmin' uitgedeel het.

5. Sonder om te rapporteer oor die vlak van besmetting van die honde in die gemeenskappe waar die navorsing gedoen is, word beweer dat die enkele ontwurming 'n tweërlei effek gehad het: eerstens, voorkoming van die velmol, en tweedens, voorkoming van die gevaar van viserale larva migrans. Hierdie afleidings kon kwalik van die data wat in die publikasie verskaf is, afgelei geword het. Hoewel ontwurming volwasse wurms uit vatbare honde (meesal die jonges) sal verwyder en sekerlik' $n$ rol in beheer kan speel, sal ' $n$ enkele ontwurming van 'n populasie honde beslis nie (soos in die publikasie gestel) die gevaar van velmol of viserale larva migrans voorkom nie. Eerstens is dit alombekend dat somatiese larwes van beide Toxocara canis en Ancylystoma caninum vir lang tydperke in die weefsels van besmette honde oorleef en opeenvolgende werpsels hondjies besmet - tot soveel as vier opeenvolgende werpsels na 'n enkele besmetting van 'n teef met $A$. caninum ${ }^{1}$. Weinig wurmmiddels het veel effek op hierdie larwes. Verder oorleef die eiers van die spoelwurmsoorte van honde maande lank in hul omgewing. Daar is dus heel moontlik oorgenoeg bronne van herbesmetting vir die honde oor, om die besmettings te laat voortduur.

Die outeurs stel dat hulle aanvaar dat die gemeenskap nou verstaan hoe om die siekte (velmol) te voorkom, en dit doen deur hondemis te verwyder en die honde te ontwurm. Waarom word die waargenome vermindering in die gevalle van velmol dus, soos gestel, slegs aan die ontwurming van die honde toegeskryf? Bykomend wat van die verdere moontlikheid dat die gemeenskap dalk nou versigtig is om kinders weg te hou van plekke wat moontlik vir besmetting gevaarlik kan wees? Daar kan sekerlik nie net aanvaar word dat dit alleenlik die ontwurming van die honde was wat die gewensde effek gehad het nie. Daar word tog in die bespreking vermeld dat, as die honde slegs ontwurm sou gewees het sonder om die gemeenskap in te lig, die siekte waarskynlik weer sou teruggekeer het.

6. Soortgelyks, sonder dat dit blykbaar nagegaan is, word kaalkop gestel dat die honde weens die ontwurming gesonder en vetter geword het, en dat die inligting in Tabel 3 toon dat hierdie newe-effek reeds vir die gemeenskap met die aanbreek van die inligtingsdag duidelik was. Tog bevat Tabel 3 volgens die publikasie die resultate van ondervraging van 20 persone na afloop van die inligtingsdag. Hoewel ek saamstem dat die ontwurming heel moontlik tot' $n$ mate die kondisie van die honde kon verbeter het, lyk dit nie volgens die inligting in die publikasie asof dit vanuit die resultate van die ondersoek bevestig kan word nie. As daar met die inligtingsdag enigiets oor die effek van wurmbesmetting op die kondisie van die honde gesê is, kan hierdie inligting nie weer aangebied word as aanduiding dat die gemeenskap vanself' $n$ verbetering in die kondisie van die honde waargeneem het nie.

\section{VERWYSING}

1. Reinecke R K 1983 Veterinary helminthology. Butterworths, Durban

\title{
J A van Wyk
}

Helmintologie Seksie, Onderstepoort Veeartsenykundige Instituut, Privaatsak X05, Onderstepoort, 0110 Suid-Afrika. 